\title{
Skotland stemmer om selvstændighed
}

\author{
Af Henrik Larsen
}

Meningsmålingerne peger på et nej til Skotlands uafhængighed. Men nej'et vil alligevel få meget store konsekvenser på såvel de britiske øer som i resten af Europa. Skotterne vil formentlig få mere selvstyre, og det britiske forhold til EU kan blive påvirket på længere sigt.

Den 18. september skal der i Skotland holdes folkeafstemning om landets fremtid inden for Storbritannien. Et ja til uafhængighed vil betyde, at Skotland i 2016 vil slutte sig de godt 200 andre stater i verdenssamfundet og hermed formelt bryde med over 300 år som en del af Storwbritannien.

Men hvad er baggrunden for afstemningen, og hvad handler skotsk nationalisme om? Og hvad betyder afstemningen om uafhængighed for Skotland, Storbritannien og i bredere forstand for Europa. Hovedtanken i denne artikel er, at både et ja og måske mere overraskende - et nej vil have store konsekvenser ikke bare for Skotland, men også for den britiske unions fremtidige form og indirekte også for Europa.
I det følgende gives først en baggrund for Skotlands placering i UK og indførelsen af skotsk hjemmestyre i 1999. Dernæst zoomes der ind på den aktuelle afstemning om selvstændighed, og den skotske nationalisme som fænomen analyseres. Sidste del af artiklen handler om konsekvenserne af afstemningen for Skotland, Storbritannien og Europa ved henholdsvis et ja og et nej.

Efter Skotlands union med England og Wales i 1707, hvor det skotske parlament blev opløst og magten overført til Westminster, ophørte Skotland ikke med at opfatte sig selv som et særligt politisk system og en nation. Skotland havde fortsat egne love for uddannelse og kirkeforhold samt eget retssystem. Mange love vedtaget i Westminister gjaldt ikke eller fik en anden form i Skotland. Skotterne kom til at betragte sig som en del af en britisk union, som de stærkt bidrog til at forme industrielt og intellektuelt og udvikle til en verdensmagt med kolonier og deltagelse i 2 verdenskrige. Unionen blev et udtryk for ligeværd med den store nabo mod syd. Samtidig var der klart 2 lag i skotternes identitet: den skotske og den

Henrik Larsen er lektor og Jean Monnet professor ved Institut for Statskundskab, Københavns Universitet. Han forsker i europæisk politik, herunder det britiske forhold til EU. 
britiske. For englænderne var en skelnen mellem England og Unionen ikke så klar; i England blev UK ofte forstået som "England writ large".

Med nogle få undtagelser kom selvstændighedsspørgsmålet først for alvor på dagsordenen i det 20. århundrede. Efterkrigstidens opbygning af en UK-velfærdstat, herunder sundhedssystemet National Health Service, blev i vidt omfang opfattet som en britisk ting, og de politiske kampe omkring dannelsen af velfærdsstaten gik på tværs af England, Skotland, Wales og Nordirland. Selvstændighed dukkede op i forbindelse med fund af olie i Nordsøen omkring 1970, hvor Det Skotske Nationalistparti (SNP) fik valgt sine første medlemmer til det britiske parlament. Et forslag til et begrænset skotsk selvstyre kom til folkeafstemning under en Labour-regering i 1979, men på trods af et snævert flertal ledte jaet ikke til selvstyre, idet der ikke blev afgivet de fornødne $40 \%$ ja-stemmer.

\section{Selvstyre fra 1999}

Da Labour igen kom til magten i 1997 efter at De Konservative havde været i regering gennem 18 år, havde det endnu en gang et forslag om skotsk selvstyre på programmet. Ved en folkeafstemning samme år blev det et stort ja til skabelsen af et skotsk parlament med en begrænset ret til at opkræve skatter. Det første skotske parlament siden 1707 blev valgt i 1999.

Dvæler man lidt ved baggrunden for vedtagelsen af selvstyreordningen i 1997, siger noget vigtigt om dynamikken i debatten om skotsk selvstyre og selvstændighed. Skotterne var generelt mindre begejstrede for de 18 år med konservative regeringer under Margaret Thatcher og John Major fra 1979 til 1997 end englænderne. Der var større støtte til velfærdsstaten og dens institutioner end i England. Antallet af konservative parlamentsmedlemmer blandt de 72, der blev valgt i Skotland til parlamentet i Westminster i de 18 år, faldt fra 22 i 1979 til 0 i 1997.
Det store flertal af skotske parlamentsmedlemmer kom fra Labour og fra SDPLiberals og Scottish National Parti (SNP). Dette afspejlede en politisk kultur i Skotland, der lagde mere vægt på kollektivisme og velfærdsstatstænkning end især i Sydengland. Skotterne anså i højere og højere grad sig selv som værende i modsætning til regeringen og den politiske kultur i London, hvad der gav vind i sejlene til SNP.

Dette peger på en dynamik, som stadig er tilstede i debatten om skotsk selvstændighed: En konservativ regering i London bidrager generelt til, at de stemmer, som ønsker mere skotsk selvstyre, får mere genklang. Det nuværende regeringsflertal har en konservativ og 11 liberaldemokrater ud af de parlamentsmedlemmer, som er valgt i Skotland. London-politikken ses især i denne situation som baseret på en anden politisk kultur end den skotske, selvom forskellene i økonomisk tænkning mellem England og Skotland nok er blevet mindre end under Thatcher-årene. I høj grad på grund af den stærke støtte til Labour i Skotland og Wales, den såkaldte Celtic Fringe, har spørgsmålet om skotsk selvstyre haft en central placering i Labours program. Det var baggrunden for Labours forslag om skotsk selvstyre i 1997. Labours regeringer har også haft en klart større andel af skotske (og walisiske) ministre end de konservative regeringer. Labours indflydelsesrige finansminister og senere premierminister Gordon Brown var skotte.

Det skotske parlament, Holyrood, der i modsætning til Westminster er valgt ved forholdstalsvalg som i bl.a. Danmark, havde i de to første valgperioder en Labourførsteminister, da Labour var det største parti i en koalitionsregering. Men ved valget i 2007 blev SNP det største parti, og ved valget i 2011 fik SNP endda absolut flertal. Dets leder Alex Salmond har været Skotlands førsteminister siden 2007. Generelt har SNP lagt sig længere til venstre end Scottish Labour. Partiet lovede, at det ville 
stille forslag om en afstemning om skotsk selvstændighed, hvis det blev genvalgt med absolut flertal i 2011, hvilket skete. De øvrige partier i det skotske parlament har efterfølgende accepteret folkeafstemningen, men anbefaler et nej!

UK-premierminister David Cameron har gennem den såkaldte Edinburgh-aftale givet håndslag på, at han vil respektere udfaldet af en sådan afstemning som afgørende.Situationen i Skotland er den, at der generelt har været stor tilfredshed med hjemmestyreordningen siden 1999, og at over halvdelen af skotterne at dømme efter meningsmålingerne gerne ser den udvidet til at omfatte flere områder og mere økonomisk ansvar - den såkaldte devo max.

Før valgkampen gik i gang, ønskede kun omkring 25 procent fuld selvstændighed. Devo max er ikke på stemmesedlen, som folk skal sætte deres kryds ved 18. september, fordi der ikke har kunnet findes politisk enighed om en formulering om, hvad devo max skulle gå ud på konkret. På den måde kan man sige, at afstemningen paradoksalt nok kommer til at handle om de 2 optioner, som færrest ifølge meningsmålingerne ønsker: status quo versus fuld selvstændighed.

På denne baggrund kan det undre, at SNP alligevel har ønsket en folkeafstemning om fuld selvstændighed. Ifølge SNPførsteminister Salmond i den skotske regeringspublikation Scotlands Future fra november 2013 er der imidlertid tale om en "once in a-generation chance to chart a better way". Her fremhæves tre grunde til, at SNP ønsker skotsk selvstændighed:

1) Det skotske folk kan bedst tage vare på Skotlands interesser (et kernepunkt i de fleste kampe for national selvbestemmelse). Regeringerne i London har i mange tilfælde ikke været i overensstemmelse med skotske politiske ønsker - i 34 ud af 68 år siden 1945 har der været uoverensstemmelse mellem regeringens farve i London, og hvad flertallet af de skotske vælgere har stemt. Det er ikke på grund af en særlig hi- storisk mission eller lignende, at Skotland skal blive selvstændigt igen, men på grund af "the real democratic value".

2) Skotland vil blive et mere velstående land, når det får et parlament, som alene tager udgangspunkt i skotske interesser. De nordiske lande nævnes som relevante eksempler på, at stater af samme størrelse som Skotland klarer sig bedre gennem uafhængighed.

3) Der vil blive skabt et mere fair samfund, som retter op på uønskede uligheder skabt af mange år under Westminsters regeringer. Der vil opstå en social nation: et land, der handler og føler sig som et fællesskab. Forholdet mellem landene på de britiske øer vil også være sundere for alle parter, hvis de er baseret på ligeværdige nationer.

\section{Independence Lite}

SNP ønsker således at kappe de politiske forbindelser til UK, men samtidig ønsker det at fastholde medlemskabet af fem unioner. Eller som førsteminister Salmond udtrykker det: Skotland vil "sever political ties with the rest of Britain, but unions of currency, monarchy, society, Europe and defence would remain".

SNP ønsker, at Skotland skal løsrive sig fra de politiske bindinger til UK gennem at blive en selvstændig stat. Men samtidig ønsker SNP at fastholde pundet som valuta i en møntunion med resten af UK. Det ønsker også, at Skotland fortsat skal være underlagt det britiske kongehus. Det ønsker en "samfundsmæssig union", hvor der ikke skal vises pas, når der rejses til rest-UK (altså ikke medlemskab af EU's Schengen-område), og hvor de talrige familiære forbindelser kan fortsætte. Det ønsker ligeledes, at Skotland bliver medlem af EU og også fortsætter som del af NATO - dog uden deployering af kernevåben på skotsk grund. På baggrund af det fortsatte skotske medlemskab af de fem unioner, har flere kommentatorer brugt termen "independence lite" om SNP's uafhængighedsforståelse en term, som SNP ikke har afvist.

"Indepencence lite" kan ses som en tilpas- 
ning af SNP's uafhængighedsprojekt til den skotske befolknings præferencer. Men ønsket om deltagelse i de fem unioner efter eventuel uafhængighed stikker også dybere og har også rod i den senmoderne nationalisme i en britisk og europæisk kontekst, som SNP formulerer sig ud fra. SNPs nationalisme er en inkluderende form for nationalisme.

Det er en politisk baseret nationalisme med få etniske markører. Der er i kampagnen få referencer til en keltisk fortid, klaner eller skotske kongefamilier. For SNP er en skotte en person, der bor eller er født i Skotland og dette inkluderer også den store gruppe af mennesker og deres efterkommere, der er emigreret til Skotland fra det britiske imperium og andre dele af verden samt den store gruppe mennesker, der flytter ind og ud af Skotland fra det øvrige UK.

Samtidig lægger SNP vægt på Skotlands særlige politiske kultur (der især sættes over for Westminster-kulturen) som baggrund for selvstændighed. Det er med andre ord en nationalisme, hvor de lag af identiteten, der væver Skotland sammen med især det øvrige UK gør, at nationalismen får en mindre skarp og konfrontatorisk form. Det bliver en form for nationalisme lite, hvor der ikke er en klar oppositionel modstilling til en anden, og der er en række områder, hvor SNP ikke ønsker at kappe båndene til UK. Dette har fået debattører som Jura-professoren Neil Walker fra Edinburgh University til at spørge, hvilken mening det giver at ønske statslig selvstændighed i dagens Europa, når man i samme åndedræt nævner alle de forbindelser, man fortsat ønsker til den stat man bryder ud af.

\section{Better Together}

SNP's kampagne for skotsk selvstændighed er fra regeringen og de øvrige UKpartiers side blevet mødt med kampagnen "Better Together", som ledes af den tidligere Labour finansminister, skotten Alistair Darling. Better Together-kampagnen argumenterer for et nej på baggrund af Stor- britanniens historiske bedrifter, men især ud fra, at Skotland på en række økonomiske og udenrigspolitiske områder vil være langt bedre stillet ved at blive indenfor UK.

Et væsentligt punkt i debatten indtraf, da finansminister David Osborne i marts i år gjorde det klart, at et selvstændigt Skotland ikke kunne vente at bevare pundet som valuta. Synspunktet blev støttet af de øvrige britiske partier i parlamentet. Man har fra regeringens side ligeledes lagt vægt på, at Skotland ikke vil kunne gå lige ind i internationale organisationer uden egentlige optagelsesforhandlinger i modsætning til, hvad der hævdes af SNP. EU inddrages sjældent i diskussionen med undtagelse af spørgsmålet om, hvorvidt Skotland automatisk vil blive medlem af Den Europæiske Union efter selvstændighed. Der er derfor få, som påpeger det umiddelbare paradoks i, at den euroskeptiske del af Det Konservative Parti mener, at Skotland vil have det bedre indenfor den britiske union, mens UK vil have det bedre udenfor Den Europæiske Union!

Det har i høj grad været de praktiske komplikationer ved et ja, som Better Together-kampagnen har slået på, snarere end en gen- eller nyformulering af en UK-identitet. Det har på sin vis været nej-kampagnens største svaghed. Samtidig har man også, som debatten er skredet frem i foråret, set flere forslag om devo max fra Labour og Liberaldemokraterne som en måde at imødekomme skotterne med andre attraktive muligheder end et ja. Denne kampagne er dog hæmmet af, at de to partier har forskellige devo-max planer. I marts kom premierminister $\mathrm{Ca}$ meron også på banen, idet han i en tale til Det Konservative Parti i Skotland mere end antydede, at også De Konservative ville støtte yderligere skotsk selvstyre.

Liberaldemokraterne har det mest vidtgående forslag med en meget høj grad af internt selvstyre og mulighed for udskrivning af skatter. Labour forsøger interessant nok at 
formulere sit projekt som en del af en nyformulering af rationalet for UK: nok skal skotterne have mere selvstyre, også på det økonomiske område, men de centrale elementer af velfærdstaten skal forblive britiske.

På sin vis kan man sige, at ja- og nejkampagnerne (og dem, der støtter dem) rykker mod midten og dermed nærmer sig hinanden. Better Together bevæger sig i retning af at give skotterne mere selvstyre (selvom der ikke er en fælles front på dette punkt), mens SNP's formuleringer bevæger sig i retning af at lade selvstændighed betyde mindre i kraft af fastholdelsen af de fem unioner.

\section{Konsekvenserne}

Konsekvenserne af et ja vil være, at Skotland bliver en uafhængig stat. I den såkaldte Edinburgh-aftale, som også er accepteret af det britiske parlament, har Cameron gjort det klart, at regeringen accepterer folkeafstemningen som legitim. Der skal så være forhandlinger mellem en skotsk regering og Storbritanniens regering. Her vil skotterne være i en demandeur position, så det er ikke klart, hvor mange af deres krav, de kan få opfyldt. Omvendt er det også klart, at mange af Londons positioner kan blive blødt op. Det gælder f.eks. afvisningen af at dele pundet med skotterne.

For Skotland vil der naturligvis være mange og væsentlige konsekvenser af administrativ, politisk og identitetsmæssig karakter. Skotland skal have en skriftlig forfatning forskellig fra den uskrevne britiske, men på linje med de fleste andre lande i verden. Et centralt spørgsmål knytter sig til SNP. Vil SNP miste sin raison d'être efter selvstændighed eller vil det tilpasse sig og fortsat spille en politisk rolle, som det har været tilfældet med selvstændighedspartier i andre dele af verden? Ved hidtil at placere sig til venstre for Labour, har SNP på sin vis skabt sin egen politiske platform som kunne føre videre i et uafhængigt Skotland. Men i et uafhængigt Skotland vil
Scottish Labour ikke længere skulle tilpasse sig British Labours politiske linje, så måske vil Labour på sigt placere sig tættere på SNP og muligvis genvinde sin plads som største i det skotske parlament.

På den udenrigspolitiske side tegner det mest til, at Skotland skal genansøge om medlemskab af EU, NATO og andre internationale organisationer i overensstemmelse med den britiske regerings hvidbog om dette. En ansøgning om EU-medlemskab burde umiddelbart være en ekspeditionssag al den stund, at Skotland som del af UK har været med i EU i mere end 40 år, og skotsk lovgivning derfor burde være i overensstemmelse med EU's acquis. Men Kommissionsformand Barroso har gjort klart, at Skotland vil skulle gå igennem den almindelige optagelsesprocedure.

Samtidig er der nogle meget tunge spørgsmål gemt i denne umiddelbare ekspeditionssag. Den skotske regering ønsker fortsat møntunion med UK og ikke deltagelse i euroen. Dette har den konservative britiske finansminister, Liberaldemokraterne og Labour sagt klart nej til, om end det ikke helt kan udelukkes, at spørgsmålet vil blive genovervejet efter folkeafstemningen i lyset af, hvad der vurderes at være den britiske interesse på det tidspunkt.

Samtidig er det ikke indlysende, at et nyt medlemsland vil kunne få forhandlet en undtagelse fra euroen. En tilsvarende problematik knytter sig til tilknytningen til Schengenområdet, som UK og Irland jo ikke er del af. SNP ønsker en fortsat "social union", hvor der ikke skal vises pas mellem Skotland og øvrige dele af de britiske øer. Men vil Skotland kunne forhandle sig til en permanent status uden for Schengen? Den britiske regering har ikke afvist et "common travel area" med Skotland, hvilket peger på, at der ville være rest-britisk støtte til dette, hvis der kan findes enighed om immigrationspolitiken.

Hertil skal lægges, at et land som Spanien med baggrund i Katalonien- problematikken formentlig ikke ønsker, at Skotlands 
medlemskab skal fremstå som en formsag, selvom man fra spansk side har sagt, at de to situationer ikke kan sammenlignes.

NATO-medlemskab kan umiddelbart synes at have karakter af en formsag, men der gemmer sig nogle større, vanskelige spørgsmål. Her er det især SNP's ønske om kernevåbenfrihed, der kan komplicere et medlemskab. Andre NATO-lande har også haft reservationer over for stationering af kernevåben i fredstid. Men Storbritanniens atomubåde med Trident-missiler, som er den eneste operationelle nukleare komponent i britisk forsvar, har altid været stationeret i skotske lochs, når de ikke sejler rundt på verdenshavene. Og en accept af en skotsk status som kernevåbenfri vil betyde et stop for ubådsbaser og sandsynligvis også rest-britiske ubådes bevægelsesfrihed inden for de britiske øer. Skotsk NATO-medlemskab med kernevåbenfrihed vil derfor nødvendiggøre en praktisk omlægning af rest-UKs kernevåbenforsvar, hvad der formentlig ikke vil gøre restUK venligt stemt over for et skotsk NATOmedlemskab under disse betingelser.

For UK vil konsekvensen forventeligt blive, at der vil blive længere mellem Labour-regeringerne i det rest-britiske parlament, hvis Labour da nogensinde kommer til magten igen med absolut flertal i rest-Storbritannien. Skotland (og i mindre grad Wales) er langt mere orienteret mod Labour end England. Skotland har i de sidste 30-40 år stort set kun valgt Labour medlemmer til Underhuset i Westminster. Cirka ti procent af medlemmerne af Underhuset har således næsten konstant været Labour-medlemmer fra Skotland. I et langt mere konservativt orienteret England skal Labour flytte så mange stemmer uden "hjælp" fra Skotland, at det vil komme tæt på at være praktisk umuligt. Labour i restUK vil formentligt bevæge sig politisk mod det konservative parti og Liberaldemokraterne af samme grund.

Et Storbritannien, der er endnu mere præget af det konservative parti, vil også være et Storbritannien, der er mere præget af den herskende skepsis over for EU hos dette parti. Generelt er Skotland mere begejstret for EU end England. Og hvis det skulle komme til en afstemning om restStorbritanniens medlemskab af EU med en eventuelt genvalgt konservativ regering i 2017 eller senere, vil fraværet af skotske stemmer gøre et nej til fortsat britisk medlemskab langt mere sandsynligt. Det bliver i den forstand et Storbritannien, der bliver mere lukket om sig selv. Det bliver også et UK, hvis stemmemæssige styrke i EU formindskes. Det kommer jo til at få en mindre befolkning end Frankrigs.

\section{Mere selvstyre på vej}

Når alt dette er sagt, er et nej ifølge meningsmålingerne det mest sandsynlige, hvilket ikke gør ovenstående aktuelt. Men nej' et vil alligevel have meget store konsekvenser internt i UK og i Europa. Det skyldes, at antallet af ja-stemmer ud fra stort set enhver vinkel vil være betragteligt ifølge meningsmålingerne omkring $40 \%$ af de afgivne stemmer. For at fremme argumenterne for Better Together har både Labour, Liberaldemokraterne og til sidst også premierminister Cameron præsenteret forslag om en højere grad af skotsk selvstyre - det såkaldte devo max. Det kan naturligvis tænkes, at disse forslag ikke vil blive fremmet, når det først er blevet et nej. Usikkerheden om dette har netop været et argument fra SNP.

Men med ca. 40 procent ja-stemmer vil der være pres for at føre forslagene videre - også for at foregribe fremtidige skotske selvstændighedsafstemninger ved at indføre det, som alle meningsmålinger siger, at skotterne foretrækker. Konsekvensen af et nej vil derfor ud fra denne betragtning lede til yderligere skotsk selvstyre inden for UK. Måske har det været SNP's egentlige mål med afstemningen at skabe en sådan dynamik, da et ja aldrig har stå- 
et stærkest i meningsmålingerne.

Et nej betyder i første omgang, at spørgsmålet om et nyt land i Europa og konsekvenserne for det tilbageværende UK ikke bliver aktuelt. Men samtidig får Skotland i endnu højere grad selvstyre. Det kan være, at devo max skaber et nyt ligevægtspunkt, hvor forslag om fuld selvstændighed ikke vil have politisk relevans, fordi et flertal af vælgerne er tilfredse med dette udvidede selvstyre. Dette var netop den uudtalte antagelse i Labour-regeringens forslag, som ledte til den nuværende selvstyrelov i 1997.

Men det kan ikke udelukkes, at det også give en endnu stærkere platform for SNP til at ønske fuldt selvstændighed end den nuværende selvstyreordning har vist sig at være. Alt andet lige udvander mere skotsk selvstyre den mytiske doktrin om det britiske parlaments stærke status som bærer af britisk suverænitet, som Storbritannien har bygget på i 300 år.

Da netop doktrinen om parlamentarisk suverænitet har været et omdrejningspunkt for skepsis over for afgivelse af suverænitet til EU, har dette også betydning for forholdet til EU. Når Storbritannien i stigende grad er delt i lag, hvor nationerne i højere grad er selvstyrende i en særdeles heterogen form for føderalisme med Westminsterparlamentet som toppen på kransekagen, kan et EU-lag ovenpå synes mindre kontroversielt.

Den tidligere konservative udenrigsminister Lord Howe skrev for over 20 år siden, at den britiske skepsis over for uklare, delvis overnationale, EU-beslutningsstrukturer var overraskende på baggrund af den flerhed af styreformer, der havde karakteriseret det britiske imperium (kronkolonier, dominions, protektorater, almindelige kolonier og naturligvis Westminster). Det samme kan siges om de interne britiske styreformer, som har udviklet sig siden den britiske de- centraliseringslov i 1997 og den udvikling, der vil følge af den skotske afstemning.

Samtidig har man også set en stærkt stigende konservativ EU skepsis, som er lejret i England og det konservative partis stærke basis i landet. En skepsis, der i høj grad er bundet op på understregningen af Westminster-parlamentets status og truslen mod samme fra EU. Spørgsmålet om yderligere skotsk selvstyre er derfor knyttet til spørgsmålet om UK og EU på en mere indirekte men ikke mindre interessant måde. Det er også knyttet sammen på den måde, at det er blandt euro-skeptikerne hos de konservative, at man finder dem, som går mest går ind for stærke Westminster-strukturer og mindre regionalt selvstyre.

De store spørgsmål om interne sammenhængsformer i UK og i en videre forstand UKs skæbne forbliver derfor på dagsordenen. Og det er spørgsmål, der er forbundet med UKs forhold til EU. De, som går ind for en stærk Westminster-centreret statsform er ofte også dem, der går ind for en løsere tilknytning til EU. Når det omvendte ikke er tilfældet, skyldes det, at de fleste politiske partier, også de EU-skeptiske konservative, nu af pragmatiske grunde støtter en eller anden form for øget skotsk hjemmestyre. Ikke fordi de kan lide det, men som en reaktion på de forventede mange ja-stemmer ved den kommende afstemning.

Et UK med det suveræne parlament i London som det politiske omdrejningspunkt kan derfor blive ændret på længere sigt som reaktion på den skotske afstemning og i bredere forstand de skotske og walisiske hjemmestyrers succes. Det kan få konsekvenser for Europa-debatten i UK. En løsere UK-union kan på kort og mellemlang sigt lede til endnu mere fokus på at fastholde Westminsters magt over for EU. 